\title{
The Utilization of Wuluh Starfruit for Making Facial Cleansing Solid Soap
}

\author{
Dian Maulina $^{\mathrm{a}, 1, *}$, Riski Sartika ${ }^{\mathrm{b}, 2}$ \\ ${ }^{a}$ Industrial Engineering Study Program, South Aceh Polytechnic, South Aceh Regency, 23711, Indonesia \\ ${ }^{b}$ Industrial Engineering Study Program Student, South Aceh Polytechnic, South Aceh Regency, 23711, Indonesia \\ 'dianmaulina312@gmail.com*, 2 riskisartika97@gmail.com
}

ARTICLE INFO

Article history:

Accepted

Keywords:

Starfruit

Solid Soap

Facial Cleansing

Face Wash Stick

\section{ABSTRACT}

Belimbing wuluh is one of the species in the family (Averrhoa). It is estimated that this plant comes from tropical America, this plant grows well in its country of origin, while Indonesia is mostly kept in the yard and sometimes grows wild in the fields or forest edges. In general, wuluh starfruit for the people of Aceh is used as a spice called Sunti acid. Starfruit can also be used as a raw material for making soap which has properties to inhibit premature aging and overcome acne problems because starfruit contains vitamins A and C. Belimbing wuluh is also known as a plant that grows in the yards of Acehnese houses, which every time it bears fruit it will produce quite a lot of fruit, if it is not used for making processed products, the fruit will rot on the tree or fall on the ground. Based on the abundant raw materials, this research will focus on "Utilization of Starfruit for Making Facial Cleansing Solid Soap". The purpose of this research is to make solid soap with additional ingredients of starfruit, and produce solid facial soap from starfruit in the form of face wash sticks so that it is easy to use. The research method used is an experimental method which produces three samples that meet the 2016 SNI standard with a moisture content of $10 \%$ and a degree of acidity $(\mathrm{pH}) 10$. From the three samples, the first sample had a hardness that matches the characteristics of solid soap.

Copyright (C) 2021 Politeknik Aceh Selatan. All rights reserved.

\section{Introduction}

Indonesia is a country that is famous for its diversity of plants, especially agricultural products and spices. This is supported by the geographical condition of Indonesia which has a tropical climate with frequent rainfall throughout the year. One of the diversity found in Indonesia is starfruit (Averrhoa bilimbi L). Belimbing wuluh lives in almost all areas but has not been cultivated specifically [4].

In general, wuluh starfruit for the people of Aceh is used as a spice called sunti acid. Belimbing wuluh is also known as a plant that grows in the yards of Acehnese houses, which every time it bears fruit it will produce quite a lot of fruit, if it is not used for making processed products, the fruit will rot on the tree or fall on the ground.

Belimbing wuluh can also be used as a raw material for making soap which has properties to inhibit premature aging and overcome acne problems because starfruit contains vitamins $\mathrm{A}$ and $\mathrm{C}$. Vitamins $\mathrm{A}$ and $\mathrm{C}$ act as antioxidants that can affect the skin so that the skin will feel soft, and fresh. . In addition, the acid content in vitamin $\mathrm{C}$ is also able to kill germs attached to the surface of the skin, germs that usually cause acne and irritation of the facial skin. Black spots are gradually disguised when you routinely carry out maintenance with wuluh starfruit solid soap. 


\section{Basic Theory}

\section{A. Definition of Soap}

Soap is the result of the addition of fatty acids and bases. This event is known as the saponification event. The process of saponification which is the reaction of a fat or glyceride with a base. Soap fats from saturated and long-chain saturated fatty acids (C16-C18) produce hard soaps and oils from short-chain unsaturated fatty acids (C12-C14) produce softer and more soluble soaps. Liquid soap and solid soap are different. To make solid or hard soap used alkali in the form of sodium hydroxide $(\mathrm{NaOH})$, while to make liquid soap using potassium hydroxide $(\mathrm{KOH})[3]$.

\section{B. Starfruit}

Wuluh starfruit or vegetable starfruit, sour starfruit or reed starfruit is a plant that has a rich sour taste and is often used as a vegetable seasoning or a mixture of herbs and spices [8].

\section{Sodium hydroxide ( $\mathrm{NaOH})$}

Sodium hydroxide $(\mathrm{NaOH})$ is a strong base that accepts a proton from $\mathrm{Na}+$. Sodium hydroxide contains an element of the alkali group, namely Sodium. The characteristics of the alkali group such as strong reducing agents and being able to reduce acids, easily soluble in water, are good conductors of electric current and heat, the order of reactivity increases with increasing atomic weight [5].

\section{Palm oil}

Palm Oil is an industrial/plantation plant that is useful as a producer of cooking oil, industrial oil, and fuel. Oil palm trees consist of two species, namely elaeis guineensis and elaeis oleifera which are used for commercial agriculture in the production of palm oil [1].

\section{E. Olive oil}

Olives have the scientific name Olea europaea which is still included in the family oleaaceae. Olive trees begin to produce fruit at the age of five. At the age of 15-20 years, olive trees are able to produce full fruit and can survive for hundreds of years. Young olives that are yellowish green are often used by the community as a flavoring spice in food. Meanwhile, ripe olives are purpleblack in color and are often extracted for the oil known as olive oil. Olive oil is also used as cooking oil, cosmetics and as a mixture for making soap [6].

\section{F. Face Wash Stick}

Face Wash Stick is a rod-shaped face wash that is easy to apply and easy to carry everywhere. The preparation is similar to the manufacture of emulsions in which an oil phase (Fatty acid) is stirred in a solution or alkali phase at a temperature of about $70-80$. then filled into a stick container and let it solidify. [2].

\section{Method}

In the manufacture of Solid Soap for the Face in the form of a Face Wash Stick from starfruit Wuluh using an experimental method. Experimental is observation under artificial conditions where the conditions are made and regulated by the researcher [7]. 


\section{A. Tools and Materials \\ 1. Tool}

The tools used in this study are as follows in Table 1.

Table 1. Tools used

\begin{tabular}{clcc}
\hline No & Equipment Name & Amount & Unit \\
\hline 1 & Measuring cup & 1 & Fruit \\
\hline 2 & Mixer & 1 & Set \\
\hline 3 & Receptacle & 4 & Fruit \\
\hline 4 & Stick & 3 & Fruit \\
\hline 5 & Pot & 1 & Fruit \\
\hline 6 & Digital scales & 1 & Fruit \\
\hline 7 & Blender & 1 & Fruit \\
\hline 8 & thermometer & 1 & Fruit \\
\hline 9 & Paper PH Meter & 3 & Fruit \\
\hline 10 & Spoon & 3 & Fruit \\
\hline 11 & Filter & 1 & Fruit \\
\hline 12 & Triangle plastic & 3 & Fruit \\
\hline
\end{tabular}

\section{Ingredients}

The materials used in this study are as follows in Table 2.

Table 2. Composition of materials used

\begin{tabular}{llllll}
\hline No & $\begin{array}{c}\text { Sample } \\
\text { Name }\end{array}$ & NaOH & $\begin{array}{c}\text { Sari Starfruit } \\
\text { Wuluh }\end{array}$ & Palm oil & Olive oil \\
\hline 1 & Sample I & $10 \mathrm{gr}$ & $20 \mathrm{gr}$ & $20 \mathrm{gr}$ & $15 \mathrm{gr}$ \\
\hline 2 & Sample II & $10 \mathrm{gr}$ & $20 \mathrm{gr}$ & $15 \mathrm{gr}$ & $20 \mathrm{gr}$ \\
\hline 3 & Sample III & $10 \mathrm{gr}$ & $20 \mathrm{gr}$ & $10 \mathrm{gr}$ & $25 \mathrm{gr}$ \\
\hline
\end{tabular}

\section{B. Work Procedure Chart}

1. The process of making wuluh starfruit juice

The process for making wuluh starfruit juice is as follows:

1. Clean the wuluh starfruit from the stalk then cut it into small pieces to facilitate the smoothing process that we are going to do

2. Then wash the starfruit three times to avoid the dirt particles present in the starfruit and the acid content of the starfruit decreases.

3. After the next washing we do the wuluh starfruit refinement with a blender, this refining process without using water anymore because the wuluh starfruit has a fairly high water content.

4. After further refining the filtering process, this filtering process aims to separate the starfruit juice from the pulp.

5. After the filtering process, we will get starfruit juice.

\section{The process of making solid soap from starfruit}

The process for making solid soap is as follows:

1. The weighing process is in accordance with the composition used.

2. The process of dissolving $\mathrm{NaOH}$ with starfruit juice 
First, enter the $\mathrm{NaOH}$ into the prepared container then pour the starfruit juice into the container that has been filled with $\mathrm{NaOH}$, stir until the $\mathrm{NaOH}$ dissolves with the starfruit juice.

3. Mixing process of all ingredients

Add palm oil, olive oil and $\mathrm{NaOH}$ solution with star fruit juice, then mix until it becomes a trace, where trace is a thickened mixture condition.

4. The process of printing into the stick

After mixing all the ingredients into a trace / thicken then put it in a plastic triangle to make it easier when inserting it into the stick by occasionally tapping the floor so that the stick is densely filled, wait for it dry for 12-24 hours and the solid soap is ready.

\section{Results and Discussion}

The results of the use of star fruit for the manufacture of solid facial cleanser soap by extracting the juice is starfruit. The samples produced were three samples that met the 2016 SNI standard with a moisture content of $10 \%$ and a degree of acidity $(\mathrm{pH}) 10$. Of the three samples there was the first sample which had hardness according to the characteristics of solid soap. The resulting soap was inserted into the stick as a mold at once as a package with a length of $7.5 \mathrm{~cm}$, width $3.5 \mathrm{~cm}$ and a diameter of $1.6 \mathrm{~cm}$. The size of the soap in the stick is $4.5 \mathrm{~cm}$ long, $3.2 \mathrm{~cm}$ wide and $1.3 \mathrm{~cm}$ in diameter.

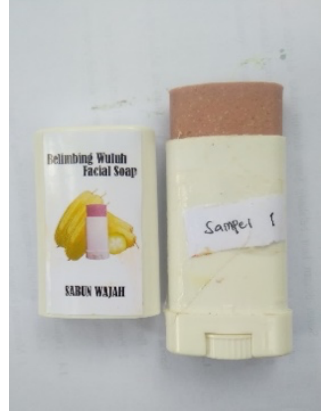

(a)

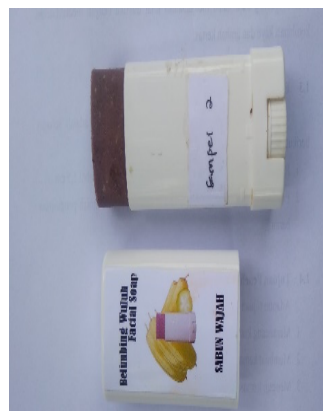

(b)

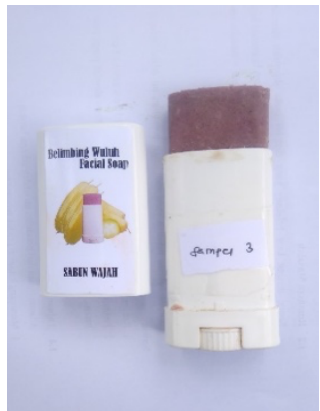

(c)

Figure 1. Samples of research results (a) sample 1, (b) sample 2 and (c) sample 3

Table 3. Criteria for solid facial cleansing soap produced

\begin{tabular}{llccc}
\hline Sample & $\begin{array}{c}\text { Color } \\
\text { before dry }\end{array}$ & $\begin{array}{c}\text { Color } \\
\text { after dry }\end{array}$ & Texture & $\begin{array}{c}\text { Occupancy Time } \\
\text { NaOH }\end{array}$ \\
\hline Sample 1 & light green & Slightly purplish & Hard & 2 weeks \\
\hline Sample 2 & Darkgreen & dark purple & $\begin{array}{c}\text { Slightly } \\
\text { mushy }\end{array}$ & 2 weeks \\
\hline Sample 3 & Darkgreen & Purple & Mushy & 2 weeks \\
\hline
\end{tabular}

From the three samples, it can be seen that the changes in color and texture are different after being left for 2 weeks. Changes in color and texture occur due to differences in composition and are directly influenced by the condition of the room during the recessing process.

\section{Conclusion}

Conclusion

From the research that has been done, the following conclusions can be drawn:

1. Belimbing wuluh can be used as an additional ingredient for making solid soap for facial cleansers by extracting the juice. 
2. Produces facial soap from starfruit which is packaged in the form of a face wash stick, this face wash stick provides convenience and efficiency in its use, and this face wash stick is also easy to carry and not easily contaminated.

3. The three samples obtained had a water content of $10 \%$ and an acidity degree of $\mathrm{pH} 10$ which met the standards according to SNI 2016.

4. The soap produced has no other ingredients added, so it still produces products without added dyes and fragrances.

2. Suggestion

From the research that has been done, the researcher gives suggestions for the future:

1. By adding soap testing to meet the standards according to SNI 2016.

2. By adding a test of addition of appropriate fragrances and dyes, so that the product is more fragrant and attractive than the previous product, making users more comfortable.

3. By continuing product marketing analysis.

4. Add a solid soap characteristic test according to SNI 2016.

5. Drying should use a suitable tool such as an oven.

\section{References}

[1] Ministry of Agriculture, Directorate General of Plantation. 2007. "Indonesian plantation statistics 20062008: Palm Oil (Oil Palm)". Secretariat of the Directorate General of Plantations : Jakarta.

[2] Directorate General of POM. (1979). Indonesian Cosmetics Formulary. Jakarta: Indonesian Ministry of Health. Thing. 83, 85, 106-132.https://www.academia.edu/18914325/Makalah_Kosmetologi_Deodoran. Retrieved 02 March 2020.

[3] Fessenden. 1997."Organic Chemistry". : Erlangga, Jakarta.http://jtk.unsri.ac.id/index.php/jtk/article/download/99/98. Accessed March 23, 2020.

[4] Hidjrawan Yusi. 2018."Identification of Tannin Compounds in the leaves of star fruit (Averhoa Bilimbi L)".Optimization Journal. Vol4 No 2 october.http://www.jurnal.utu.ac.id/joptimalisasi/article/view/1475. Retrieved February 22, 2020.

[5] Linggih, S. R and P. Wibowo. 1988."Summary of Chemistry". Ganeca. Exact Bandung. ITB, Bandung. https://intannursiam.wordpress.com/2010/07/07/laporan-ipn-4-tan-buffer/. Retrieved October 1, 2020.

[6] Resti, Ayu Sofi., 2017,"'Determination of Peroxide Numbers in Olive Oil", Scientific Works., University of North Sumatra : Medan.,http://repositori.usu.ac.id/handle/123456789/3919. Retrieved February 22, 2020.

[7] Tarjo, "3x Reading System Research Method", Yokyakarta, Indonesia: Publisher Deepublish (Grub) publishing CV BUDI UTAMA), 2019. https://penerbitbukudeepublish.cop/buku-method/m/sho. Retrieved 17 October 2020.

[8] Thomas. 2007,"Traditional Medicinal Plants 2", Kanisius, Yogyakarta, pp. 1718.http://ejournal.poltekkes-smg.ac.id/ojs/index.php/jrk/article/view/2933. Retrieved March 03, 2020. 